\title{
Effect of Tripropyltin Chloride on Functional Reactions in Escherichia coli ${ }^{\dagger}$
}

\author{
Jiro YAMADA and Tadao WATANABE* \\ Faculty of Education, Yamaguchi University, 1677-1 Yoshida, \\ Yamaguchi 753, Japan \\ *Department of Food Science and Technology, Kyushu University, \\ Fukuoka 812, Japan
}

Received January 8, 1979

\begin{abstract}
The effect of tripropyltin chloride (TPT) on some functional reactions in $E$. coli was investigated. The inhibition on respiration and protein, DNA and RNA syntheses were examined in vivo. Oxygen consumption by $E$. coli cells was scarcely inhibited even at the concentration of $30 \mu \mathrm{g} / \mathrm{ml} \mathrm{TPT}$. The incorporations of ${ }^{14} \mathrm{C}$-labeled amino acids into protein fraction were inhibited. Especially, in the case of L-leucine, it was inhibited $60 \%$ even at $10 \mu \mathrm{g} / \mathrm{ml} \mathrm{TPT}$. Both incorporations of ${ }^{14} \mathrm{C}$-adenine into DNA and RNA fraction were inhibited $50-60 \%$ at $20 \mu \mathrm{g} / \mathrm{ml}$ TPT. RNA polymerase was prepared from $E$. coli cells and the effect of organotin compounds on the enzyme activity was examined. Organotin compounds inhibited the enzyme activity only at high concentrations $(5 \sim 10 \mathrm{~mm})$, and dialkyltin chlorides which possess no antimicrobial action showed the inhibition more intensely than trialkyltin chlorides. The effect on membrane-bound ATPase was also examined in vitro. We found that TPT has high inhibitory action on membrane-bound ATPase. However, it slightly inhibited the activity of ATPase separated from membrane.
\end{abstract}

Various tin compounds have been used in a wide variety of fields. ${ }^{1 \sim 3)}$ Trialkyltin compounds (TAT) have been used as fungicide and bactericide. Many workers besides us have studied the antimicrobial action of TAT.

As reported previously, ${ }^{4}$ tripropyltin chloride (TPT) uptake by $E$. coli cells was very rapid and protoplast membrane from $E$. coli and liposomes prepared from phospholipids also possessed TPT binding ability. Furthermore, the interaction of TPT with inorganic phosphates or phospholipids was also examined. It was found that TPT could bind the compounds which possess phosphate groups in their molecular structures. ${ }^{5)}$ Considering these results we have suggested that actions of TPT on the functional reactions in the membrane might be very important in the antimicrobial action of the drug.

It is well known that various functional reactions such as respiration, ${ }^{8 \sim 8)}$ ATP synthesis, ${ }^{9 \sim 11}$ protein synthesis ${ }^{12,13)}$ and the active

+ Studies on the Antimicrobial Action of Trialkyltin Compounds. Part V. transport system ${ }^{14)}$ occur in connection with the membrane of bacteria. In this paper, therefore, the effects of TPT on respiration, protein synthesis, and DNA and RNA syntheses were examined in vivo using ${ }^{14} \mathrm{C}$-labeled amino acids and adenine. RNA polymerase (E.C. 2.7.7.6) and membrane-bound adenosine triphosphatase (E.C. 3.6.1.3 ATPase) were prepared from $E$. coli cells and the effects of TPT on the activities of these enzymes were also examined in vitro.

\section{MATERIALS AND METHODS}

Chemicals. TPT and other organotin compounds used was synthesized according to the method in the previous paper. ${ }^{15}$ Meat extract, yeast extract and bovine serum albumin (BSA) were purchased from Wako Pure Chem. Co., Osaka. ATP, GTP, CTP and DNA were products of Sigma. ${ }^{14} \mathrm{C}-U T P(50 \mathrm{mCi} / \mathrm{mm})$ and adenine $(62 \mathrm{mCi} / \mathrm{mm})$ were products of $\mathrm{RCC}$, and ${ }^{14} \mathrm{C}$-L-Leucine $(236 \mathrm{mCi} / \mathrm{mM})$ and L-proline $(50.6 \mathrm{mCi} /$ $\mathrm{mM}$ ) were products of NEN.

Medium and bacterium. Escherichia coli IFO 3301 was obtained from the Institute of Fermentation, 
Osaka. Medium A used for growth contained 1\% polypeptone, $0.5 \%$ each of meat extract and yeast extract, and $2 \%$ glucose in the phosphate buffer, $\mathrm{pH}$ 7.2. Medium $B$ used for the preparation of RNA polymerase contained $0.3 \% \mathrm{NaCl}, 0.1 \%$ glucose, $1 \%$ polypeptone, $0.0142 \% \mathrm{CaCl}_{2} \cdot 2 \mathrm{H}_{2} \mathrm{O}, 0.02 \% \mathrm{MgCl}_{2}$. $6 \mathrm{H}_{2} \mathrm{O}$ and $0.044 \% \mathrm{KH}_{2} \mathrm{PO}_{4}, \mathrm{pH} 7.0{ }^{16)}$ Medium $\mathrm{C}$ used for the preparation of membrane-bound ATPase contained $1 \%$ polypeptone, $0.3 \% \mathrm{NaCl}, 0.7 \% \mathrm{~K}_{2} \mathrm{HPO}_{4}$, $0.5 \%$ glycerol, $0.001 \% \mathrm{CaCl}_{2} \cdot 2 \mathrm{H}_{2} \mathrm{O}$ and $0.025 \%$ $\mathrm{MgSO}_{4} \cdot 7 \mathrm{H}_{2} \mathrm{O}, \mathrm{pH} 7.4{ }^{17)}$

Measurement of oxygen consumption by E. coli cells with Wargburg's manometer. One milliliter of culture pregrown for $15 \mathrm{hr}$ was inoculated into $10 \mathrm{ml}$ of fresh Medium A. When cells were grown to the middle logarithmic phase at $30^{\circ} \mathrm{C}, 3 \mathrm{ml}$ of the culture was transferred to the main cell of a Wargburg's manometer (Taiyo Wargburg's Manometer Model 0-9). After $10 \mathrm{~min}$ incubation at $30^{\circ} \mathrm{C}$, it was mixed with TPT in the sub cell to make up the final concentration of 10 , 20 or $30 \mu \mathrm{g} / \mathrm{ml}$, and oxygen consumption by $E$. coli cells was measured for $60 \mathrm{~min}$.

Measurement of oxygen uptake of $E$, coli cells with oxygen electrode. One milliliter of culture pregrown for $15 \mathrm{hr}$ was inoculated into $10 \mathrm{ml}$ of fresh Medium A. When they were grown to the middle logarithmic phase at $30^{\circ} \mathrm{C}$, cells were collected by the centrifugation at $1,500 \times g$ for $15 \mathrm{~min}$ and washed twice with $10 \mathrm{ml}$ of $0.1 \mathrm{M}$ phosphate buffer, $\mathrm{pH}$ 7.2. Then, the cells were resuspended to $1.0 \mathrm{ml}$ of the same buffer (Fresh cells suspension). This suspension was diluted to $10 \mathrm{ml}$ with the same buffer and incubated at $30^{\circ} \mathrm{C}$ for $30 \mathrm{~min}$ to decrease the amount of cellular respiratory substrates. Then, the cells were collected and resuspended to $1.0 \mathrm{ml}$ of the same buffer (Starved cells suspension). After injection of $0.2 \mathrm{ml}$ of Fresh or Starved cells suspension into $2 \mathrm{ml}$ of the phosphate buffer in the cell of a oxygen electrode Beckman Model 160C. Oxygen uptake of the cells were measured at $30^{\circ} \mathrm{C}$. Glucose $(2.5 \mathrm{~mm})$ and sodium succinate $(20 \mathrm{~mm})$ were added to the mixture as respiratory substrates.

Preparation of DNA, RNA and protein fraction from E. coli cells. A DNA, RNA and protein fractions preparation was obtained by the modification of the

$1 \mathrm{ml}$ of culture

-added $1 \mathrm{ml}$ of cold TCA
-stood at $0^{\circ} \mathrm{C}$ for $30 \mathrm{~min}$

Centrifugation

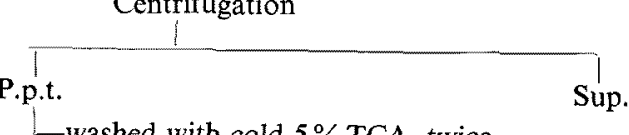

- washed with cold $5 \%$ TCA, twice

-added $1 \mathrm{ml}$ of ethanol-ether solution $(1: 1)$

- stood at $50^{\circ} \mathrm{C}$ for $20 \mathrm{~min}$

Centrifugation

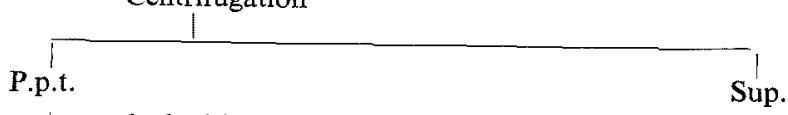

-washed with ethanol-ether $(1: 1)$, twice

-added $2 \mathrm{ml}$ of $0.3 \mathrm{~N} \mathrm{NaOH}$

-stood at $37^{\circ} \mathrm{C}$ for $18 \mathrm{hr}$

-nutralized with $6 \mathrm{~N} \mathrm{HCl}$

- added perchloric acid (PCA) (final conc. $5 \%$ )

- stood at $0^{\circ} \mathrm{C}$ for $15 \mathrm{~min}$

Centrifugation

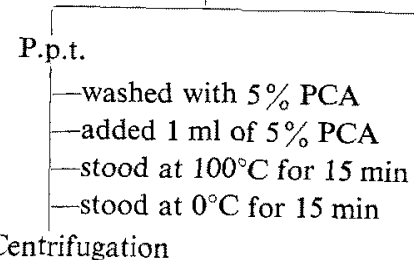

Sup.

RNA fraction

Centrifugation

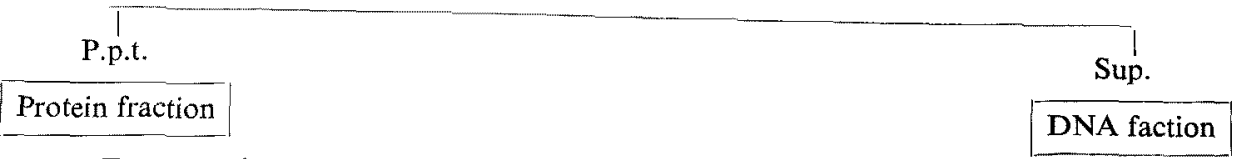

FIG. 1. The Procedures of Fractionation of Protein, DNA and RNA in E. coli. 
Schneider's method. ${ }^{18)}$ One millihiter of culture pregrown for $15 \mathrm{hr}$ at $30^{\circ} \mathrm{C}$ was inoculated into $10 \mathrm{ml}$ of the fresh medium and was grown to the middle logarithmic phase. After addition of $1 \mu \mathrm{Ci}$ of ${ }^{14} \mathrm{C}$-labeled compound to the $5 \mathrm{ml}$ of the culture, aliquots $(1 \mathrm{ml})$ were withdrawn from the reaction mixture to $1 \mathrm{ml}$ of cold $10 \%$ TCA (trichloroacetic acid) at the indicated times. The following procedures were shown in Fig. 1. All centrifugations in this experiment were performed under the condition at $1,500 \times g$ for $15 \mathrm{~min}$. The incorporations of ${ }^{14} \mathrm{C}$-labeled compounds into each fraction were counted by the use of a liquid scintillation counter Beckman Model LS-250.

Preparation of RNA polymerase from E. coli cells. A preparation of RNA polymerase from $E$. coli cells was obtained by the modification of the method of Ishihama and Kameyama. ${ }^{18)} \quad E$. coli cells grown to the middle logarithrnic phase in Medium B were harvested by centrifugation at $1,500 \times g$ for $20 \mathrm{~min}$ and washed with $10 \mathrm{~mm}$ Tris- $\mathrm{HCl}$ buffer, $\mathrm{pH} 7.6$, and $10 \mathrm{~mm}$ $\mathrm{MgCl}_{2}$. Cells $(150 \mathrm{~g})$ were broken with $200 \mathrm{~g}$ of alminium oxide in a motor with vigorous grinding for $1 \mathrm{hr}$. After addition $400 \mathrm{ml}$ of Buffer A $(10 \mathrm{~mm}$ Tris- $\mathrm{HCl}$, pH 7.6, containing $10 \mathrm{~mm} \mathrm{MgCl} 2$ and $0.1 \mathrm{~mm}$ EDTA) to them, they were stood at $0^{\circ} \mathrm{C}$ for $1 \mathrm{hr}$ to extract the polymerase. After ultracentrifugation at $35,000 \times g$ for $90 \mathrm{~min}$, protamine sulfate was added to the supernatant (crude polymerase solution) to precipitate the polymerase protein. This resultant precipitate was dissolved in $0.2 \mathrm{M}\left(\mathrm{NH}_{4}\right)_{2} \mathrm{SO}_{4}$. This solution was brought to $35 \%$ saturation by solid $\left(\mathrm{NH}_{4}\right)_{2} \mathrm{SO}_{4}$. The precipitate was removed by centrifugation, then the supernatant was made to $53 \%$ saturation with respect to $\left(\mathrm{NH}_{4}\right)_{2} \mathrm{SO}_{4}$ The precipitate obtained by centrifugation was dissolved in Buffer A containing $50 \mathrm{~mm} \mathrm{KCl}$ and dialysed for $6 \mathrm{hr}$ against 5 liters of the same solution. The polymerase was further purified on DEAE-cellulose column. The chromatography was developed with a linear gradient of $\mathrm{KCl}(0.05 \sim 0.60 \mathrm{M})$ in $500 \mathrm{ml}$ of Buffer $A$. The active fraction was concentrated to $15 \mathrm{ml}$ and same volume of glycerol was added to it (RNA polymerase solution).

Assay of RNA polymerase. RNA polymerase activity was measured by the determination of radioactivity incorporated into acid insoluble fraction. The standard reaction mixture contained $30 \mu \mathrm{mol}$ of Tris$\mathrm{HCl}(\mathrm{pH} 7.6), 1.25 \mu \mathrm{mol}$ of $\beta$-mercaptoethanol, 100 $\mathrm{m} \mu \mathrm{mol}$ of three kinds of ribonucleoside-triphosphates (ATP, GTP and CTP), $800 \mathrm{~m} \mu$ moles of ${ }^{14} \mathrm{C}$-UTP, $300 \mathrm{~mm}$ of $\mathrm{KCl}, 100 \mu \mathrm{g}$ of the enzyme and $15 \mu \mathrm{g}$ of DNA in a total volume of $250 \mu \mathrm{l}$. Each component was added in the order described above. The enzyme reaction was carried out $37^{\circ} \mathrm{C}$, and $25 \mu$ l of the reaction mixture was withdrawn and stopped at $15 \mathrm{~min}$ by adding $450 \mu \mathrm{l}$ of cold TCA and $250 \mu \mathrm{g}$ of BSA. The precipitate was washed three times with cold 5\% TCA. The incorporation of ${ }^{14} \mathrm{C}$-UMP into acid insoluble fraction was counted by the use of a liquid scintillation counter.

Preparation of crude membrane-bound ATPase. A preparation of membrane-bound ATPase was obtained by the modification of the method of Kobayashi and Anraku. ${ }^{17)} \quad E$. coli cells were grown to the middle logarithmic phase in $200 \mathrm{ml}$ of Medium $\mathrm{C}$ at $30^{\circ} \mathrm{C}$. They were harvested by centrifugation and washed twice with $10 \mathrm{mM}$ Tris- $\mathrm{HCl}$ buffer containing $30 \mathrm{~mm} \mathrm{NaCl}$, pH 7.2. The cells were broken with the same volume of glass beads and aluminum oxide ( 300 mesh) in a

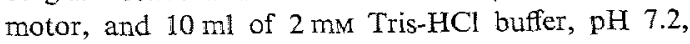
was added to them. Cell membrane was collected by centrifugation at $17,000 \times g$ for $120 \mathrm{~min}$. This membrane pellet was resuspended to $2 \mathrm{ml}$ of $2 \mathrm{mM}$ Tris$\mathrm{HCl}$ buffer, pH 7.2 (crude membrane-bound ATPase fraction).

Assay of membrane-bound ATPase. The ATPase activity was measured by means of colimetric determination of the inorganic phosphate released from ATP molecular by ATPase. The standard reaction mixture $(0.7 \mathrm{ml})$ contained $20 \mathrm{~mm}$ Tris- $\mathrm{HCl}$ buffer, $\mathrm{pH} 8.4$, $2.5 \mathrm{MM} \mathrm{Na}_{2}$-ATP, $1.0 \mathrm{mM} \mathrm{MgCl}_{2}, 10 \mu \mathrm{g}$ of BAS, and $0.1 \mathrm{ml}$ of enzyme solution. The mixture was incubated at $37^{\circ} \mathrm{C}$ for $20 \mathrm{~min}$ and reaction was stopped by addition of $0.3 \mathrm{ml}$ of $0.1 \mathrm{~N} \mathrm{HCl}$, and then, of $2.1 \mathrm{ml}$ of solution containing $0.3 \mathrm{ml}$ of $5 \mathrm{~N} \mathrm{H}_{2} \mathrm{SO}_{4}, 0.3 \mathrm{ml}$ of $2.5 \%$ ammonium molybdate $0.3 \mathrm{ml}$ of $3 \% \mathrm{NaHSO}_{3}-1 \% \mathrm{p}$ methylaminophenol sulfate, and $1.2 \mathrm{ml}$ of water. After $10 \mathrm{~min}$ at $18^{\circ} \mathrm{C}$ the optical density at $660 \mathrm{~nm}$ was determined in a Hitachi Spectrophotometer Model 139.

\section{RESULTS AND DISCUSSION}

\section{Effect on respiration of $E$. coli}

The effect of TPT on oxygen uptake by $E$. coli cells growing in the medium was examined. As shown in Fig. 2, oxygen uptake was inhibited only $10 \sim 30 \%$ (see Fig. $2 \mathrm{~A}$ ), despite the fact the growth of the cells was intensely inhibited at the same concentration of TPT; the growth was inhibited $100 \%$ at $20 \mu \mathrm{g} / \mathrm{ml}$ TPT (see Fig. 2B). However, the rate of oxygen uptake was gradually decreased at 20 and $30 \mu \mathrm{g} / \mathrm{ml}$ TPT with the elapse of time.

Furthermore, the effect of TPT on oxidation of cellular respiratory substrates was examined with Fresh cells suspension. As shown in Fig. 3A, TPT slightly inhibited the oxygen uptake attended by oxidation of cellular respiratory substrates by $E$. coli cells. The effect of 

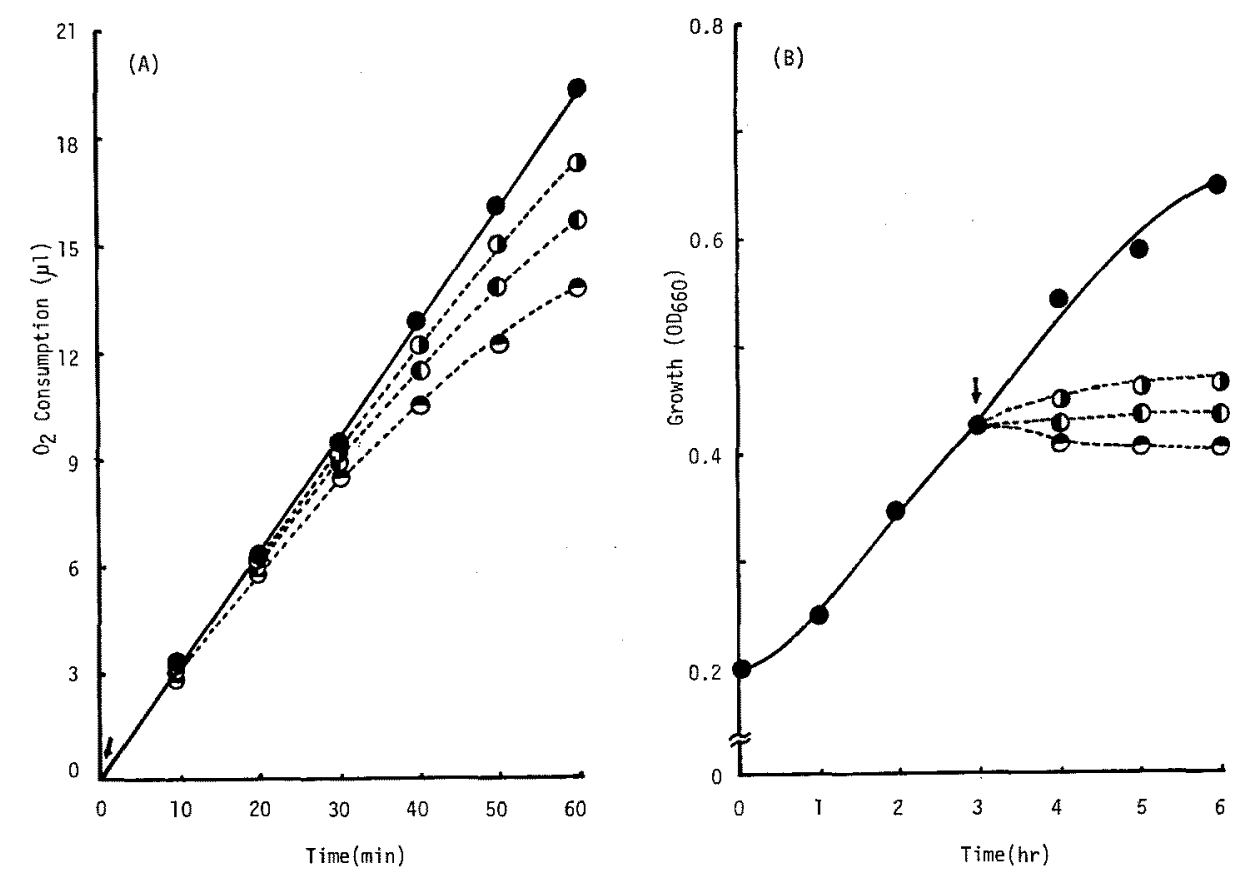

FIG. 2. Effect of TPT on the Respiration and Growth of $E$. coli.

(A), respiration; (B), growth; solid line, non-TPT (๑); broken line, TPT added $(\boldsymbol{\bullet}, 10 ; 0,20 ; \Theta$, $30 \mu \mathrm{g} / \mathrm{ml}$ ). Each arrow indicates the time of TPT addition.

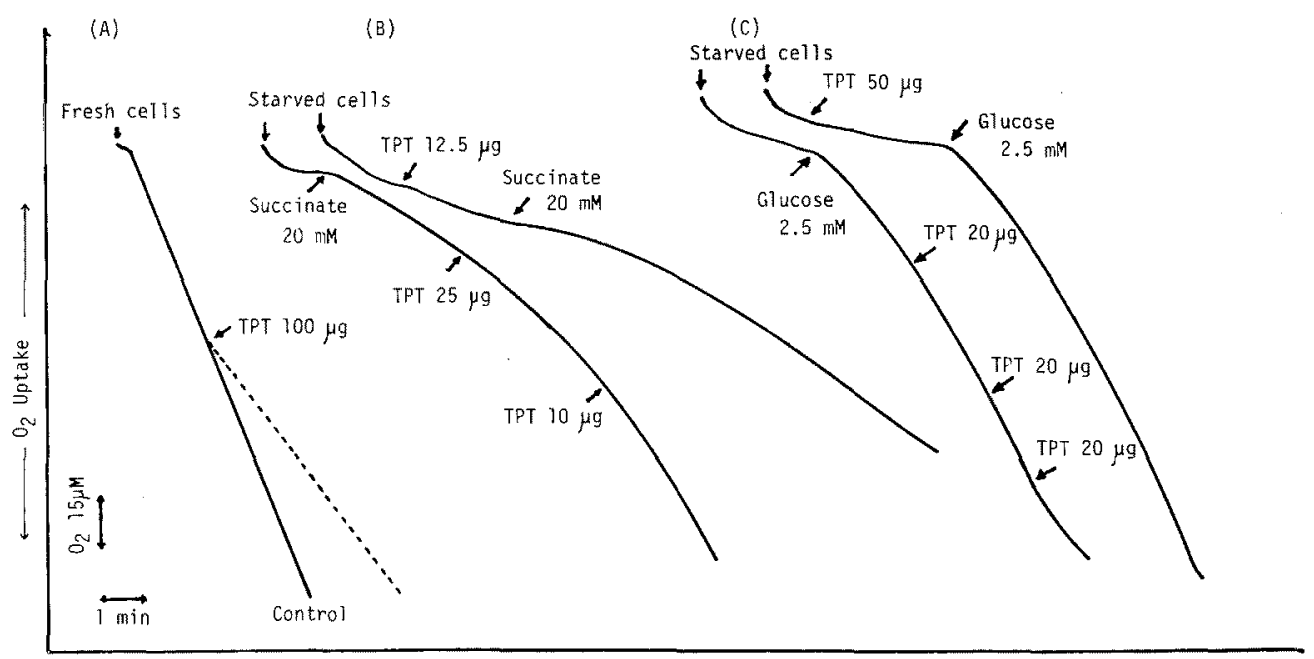

FIG. 3. Effect of TPT on the Oxygen Uptake in Starved E. coli Cells with Sodium Acetate and Glucose.

(A), Fresh cells; (B), Starved cells with sodium acetate; (C), Starved cells with glucose.

TPT on oxidation of respiratory substrates (glucose and sodium succinate) incorporated into the cells from outer reaction mixture was also examined with Starved cells suspension. As shown in Fig. 3B, when sodium succinate was added to the reaction mixture as a respiratory substrate, the oxygen uptake was not inhibited by TPT when it was added to the reaction mixture after the addition of the substrate, however, the oxygen uptake was 
intensely inhibited by TPT when it was added before the addition of the substrate. On the other hand, as shown in Fig. 3C, when glucose was added to the reaction mixture as a respiratory substrate, TPT scarcely inhibited the oxygen uptake regardless of its addition time.

The results suggest that TPT does not inhibit the oxidative reactions but the incorporation of substrate (sodium succinate) into cells.

Effect on protein synthesis of $E$. coli

The effect of TPT on protein synthesis was examined by determining the amount of ${ }^{14} \mathrm{C}$ - labeled amino acids (L-leucine and L-proline) incorporated into protein fraction in the cells. Protein fraction was prepared according to the method mentioned in MATERIALS AND METHODS. Results were shown in Fig. 4. In both cases, the incorporation of ${ }^{14} \mathrm{C}$-labeled amino acid into protein fraction was inhibited by TPT; especially in the case of ${ }^{14} \mathrm{C}$-L-leucine, it was inhibited $60 \%$ even at the concentration of $10 \mu \mathrm{g} / \mathrm{ml} \mathrm{TPT}$. As shown in Fig. 4A and B, there was a large difference in the degree of inhibition on the incorporation of L-leucine and L-proline into protein fraction.
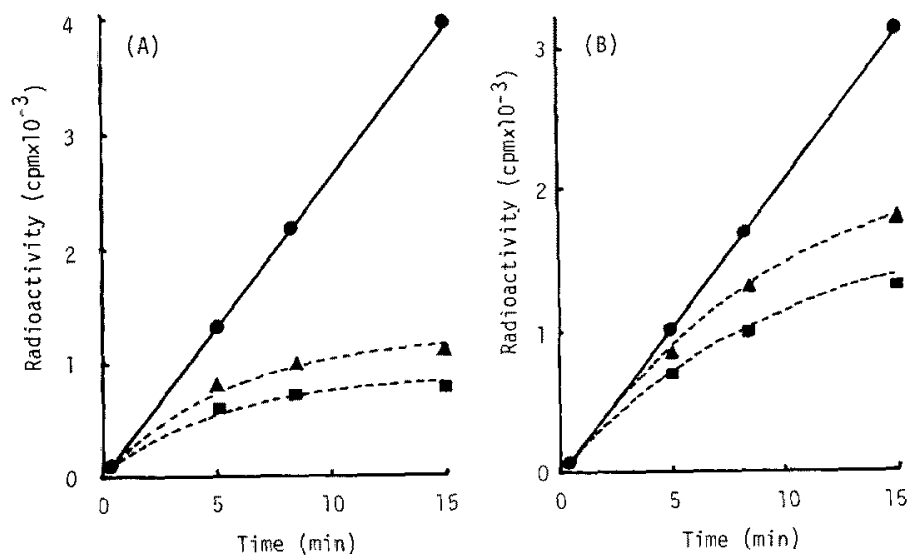

FIG. 4. Effect of TPT on Protein Systhesis in E. coli.

(A), L-leucine; (B), L-proline; solid line, non-TPT (e); broken line, TPT added $(\boldsymbol{\Lambda}, 10 ; \mathbf{m}, 20 \mu \mathrm{g} / \mathrm{ml})$
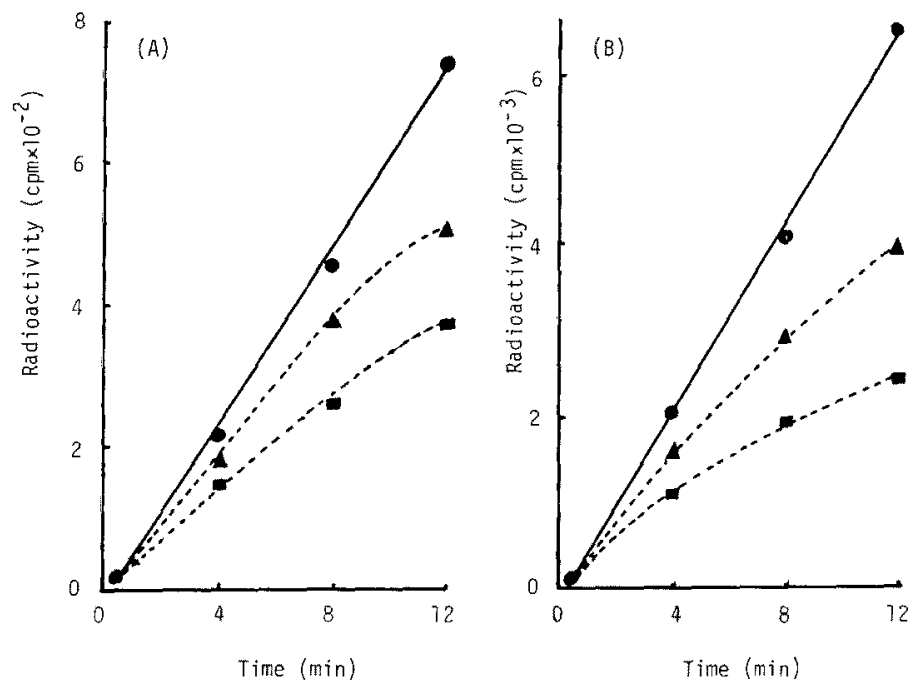

Frg. 5. Effect of TPT on DNA and RNA Syntheses in E. coli.

(A), DNA synthesis; (B), RNA synthesis. Symboles are as shown in Fig. 4. 
Effect on DNA and RNA syntheses of E. coli

The effect of TPT on DNA and RNA syntheses was examined by the determining of the incorporation of ${ }^{14} \mathrm{C}$-adenine into DNA and RNA fraction in the cells. DNA and RNA fractions were obtained according to the method given in MATERIALS AND METHODS. As shown in Fig. 5, the incorporations of adenine into DNA and RNA fractions were intensely inhibited by TPT; $50 \sim 60 \%$ at 20 $\mu \mathrm{g} / \mathrm{ml}$ and $25 \sim 30 \%$ at $10 \mu \mathrm{g} / \mathrm{ml} \mathrm{TPT}$.

Furthermore, RNA polymerase was prepared from $E$. coli cells, and the effect of TPT and other organotin compounds on this enzyme activity was examined. The result was shown in Fig. 6. Only at high concentrations ( 5 and $10 \mathrm{~mm}$ ), did both dialkyltin (DAT) and trialkyltin compounds (TAT) inhibit the enzyme activity. However, DAT which possesses no antimicrobial action ${ }^{20)}$ inhibited the enzyme activity more intensely than TAT which possesses remarked antimicrobial action. ${ }^{201}$

It is well known that nucleoside-triphosphates cannot be incorporated into $E$. coli cells from an outer medium. However, when the cells are treated with toluene, Tris or EDTA, the treated cells can incorporate nucleosidetriphosphates. ${ }^{21)}$ The effect of TPT on the incorporation of ${ }^{14} \mathrm{C}$-UTP into RNA fraction in Tris-treated cells was also examined (see Fig. 7). As control, ${ }^{14} \mathrm{C}$-adenine incorporation into RNA fraction was also examined with same treated cells. As shown in Fig. 7A, TPT inhibited $30 \sim 40 \%$ of RNA synthesis regardless of the elapse of time when UTP was added to the reaction mixture as a material of RNA synthesis. However, when adenine was added as a material of RNA synthesis, the degree of TPT inhibition on RNA synthesis gradually increased with the elapse of time, and the synthesis was stopped in $16 \mathrm{~min}$. The result suggests that TPT may inhibit a certain reaction in changing of bases to nucleosidetriphosphates.

From all the above results, it was concluded that TPT inhibition on nucleic acids synthesis might be a secondary action in the antimicrobial action of TPT.

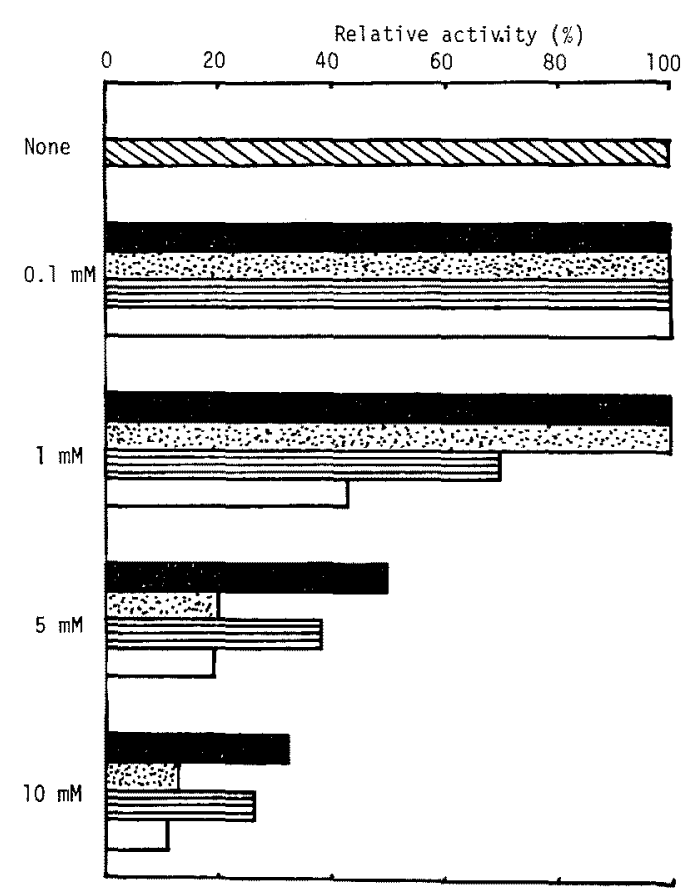

FIG. 6. Effect of Organotin Compounds on RNA polymerase Activity.

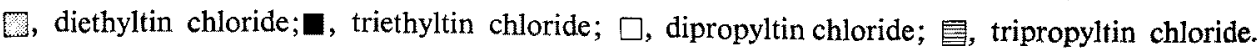



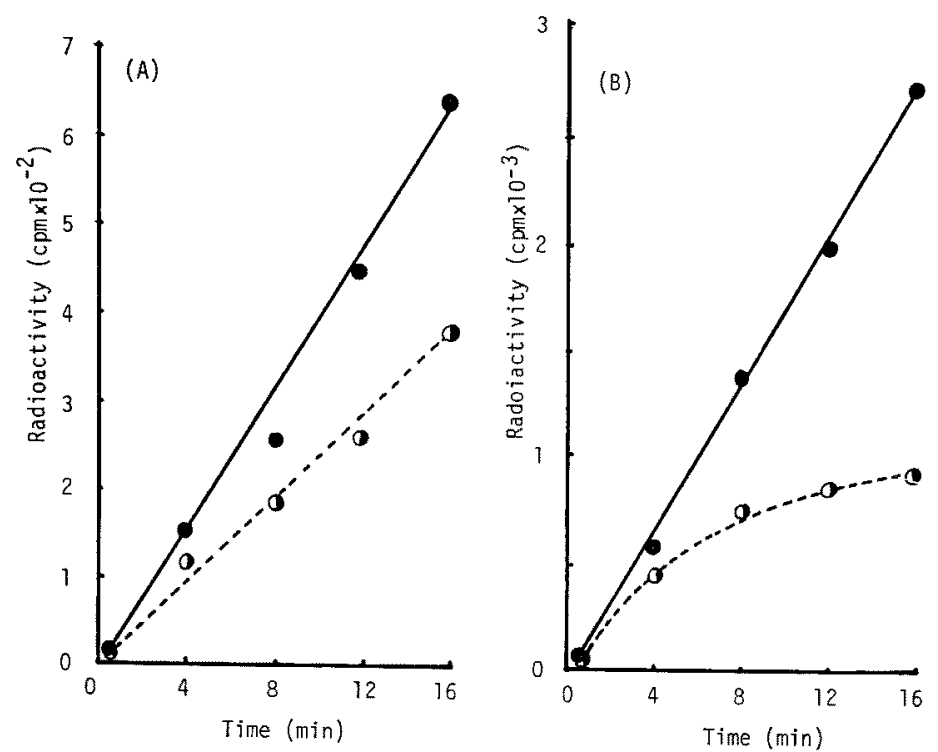

FIG. 7. Effect of TPT on Incorporations of ${ }^{14} \mathrm{C}$-UTP and ${ }^{1+} \mathrm{C}$-Adenine into RNA Fraction in Tris-treated E. coli Cells.

(A), ${ }^{14} \mathrm{C}$-UTP; (B), ${ }^{14} \mathrm{C}$-adenine; $\bullet$, non-TPT; $\mathbf{0}, 20 \mu \mathrm{g} / \mathrm{ml}$ TPT added.

\section{Effect on membrane-bound ATPase activity}

The ATPase of $E$. coli was first found in membrane fractions by Solomon. ${ }^{221}$ Voelz studied the location of ATPase by means of histochemistry and electron-microscopy and showed that it was present in the cytoplasmic membrane. ${ }^{23)}$ Various functions of this enzyme in vivo have been suggested. As reported previously, ${ }^{24)}$ it was suggested that TPT might bind to the cell membrane and disturb the normal functions of the membrane. This study examines the effect of TPT on membranebound ATPase activity with crude membranebound ATPase fraction from $E$. coli cells in vitro.

As shown in Fig. 8, TPT inhibited the membrane-bound ATPase activity intensely; $50 \%$ at $7 \times 10^{-5} \mathrm{M}$ and $90 \%$ at $5 \times 10^{-4} \mathrm{M}$ TPT. The intensity of the inhibition by TPT was the same degree as one of $\mathrm{NaN}_{3}$ which is well known as an ATPase inhibitor. However, TPT did not inhibited so intensely when ATPase was separated from the membrane. As many workers have reported previously, membrane-bound ATPase may be an important coupling factor in the oxidative phosphory-

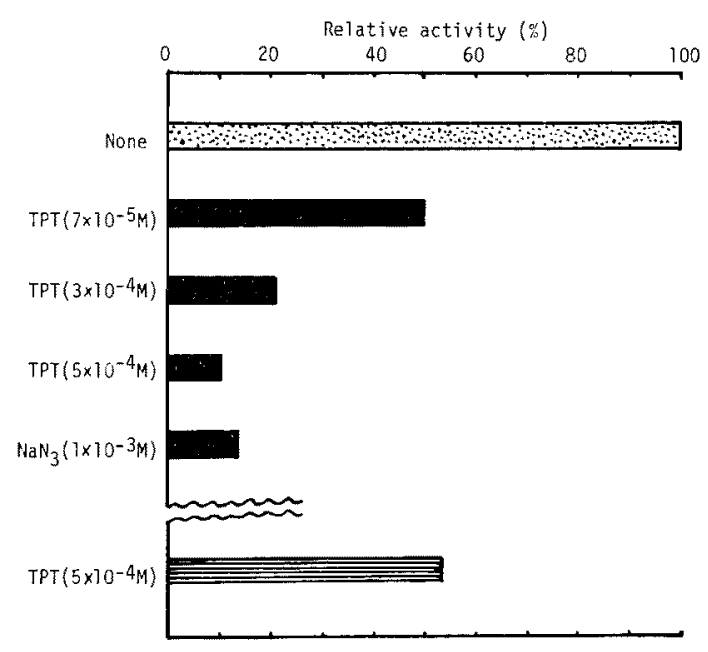

FIG. 8. Effect of TPT on E. coli Membrane-bound ATPase Activity.

a, membrane-bound ATPase; 是, ATPase separated from membrane.

lation and may be a translocating factor in the active transport system. ${ }^{25}$ ) Therefore, these results in Fig. 8 suggest that TPT may have important effects on the oxidative phosphorylation and the active transport system. 


\section{REFERENCES}

1) G. J. M. Van Der Kerk, Ind. Eng. Chem., 58, 29 (1966).

2) E. Eugene, J. Econom. Entomol, 58, 14 (1965).

3) A. Takeda, Shokuhin Eisei Kenkyu, 22, 1103 (1972)

4) J. Yamada, K. Tatsuguchi and T. Watanabe, Agric. Biol. Chem., 42, 1167 (1978).

5) J. Yamada, K. Oishi, K. Tatsuguchi and T. Watanabe, ibid., 43, 1015 (1979).

6) K. Arima, E. Sato, ibid., 34, 739 (1970).

7) S. Mizushima, J. Biolchem., 63, 317 (1968).

8) R. Baillie, C. Haw and P. Bargg, Biochim. Biophys. Acta, 234, 46 (1971).

9) G. B. Cox, F. Gibson and L. McCann, Biochem. $J ., 134,1015$ (1973).

10) J. M. Anderson, J. A. Albendea and M. Munos, Eur. J. Biochem., 37, 505 (1973).

11) S. Mizushima, Biochim. Biophys. Acta, 193, 268 (1969).

12) R. W. Hendler, Nature, 193, 821 (1962).
13) P. C. Fitz-James, Canad. J. Microbiol, 10, 92 (1964).

14) H. R. Kaback and L. S. Milner, Proc. Natl. Acad. Sci. U.S.A., 66, 1008 (970).

15) J. Yamada, K. Tatsuguchi and T. Watanabe, Agric. Biol. Chem. 42, 1167 (1978).

16) H. Murakami, S. Hatano and T. Watanabe, Shokuhin Eiseigaku Zasshi, 12, 298 (1971).

17) H. Kobayashi and Y. Anraku, J. Biochem., 71, 387 (1972).

18) W. C. Scneider, J. Biol. Chem. 164, 747 (1946).

19) A. Ishihama and T. Kameyama, Biochim. Biopys. Acta, 138, 480 (1967).

20) G. J. M. Van Der Kerk and J. G. A. Luijten, $J$. Appl. Chem., 4. 314 (1954).

21) G. Lester, J. Bacteriol. 90, 29 (1965).

22) A. K. Solomon, Biophys. J., 2, 79 (1964).

23) H. Voelz, J. Bacteriol, 88, 1196 (1964).

24) J. Yamada, K. Tatsuguchi and T. Watanabe, Agric. Biol. Chem., 42, 1867 (1978).

25) H. Kobayashi and Y. Anraku, Seikagaku, 45, 516 (1973). 